\title{
EDITORIAL
}

\section{Publicação científica: realidade e desafios}

Em agosto de 2000, editores de diversas publicações científicas de vários países estiveram reunidos, no Rio de Janeiro, durante a $10^{\mathrm{a}}$ Conferência Internacional de Editores Científicos - IFSE.

Organizada a cada dois anos, a Conferência é um evento da International Federation of Science Editors, que pela primeira vez aconteceu no Brasil, onde os editores, bibliotecários, pesquisadores puderam trocar experiências sobre os temas atuais da comunicação e da publicação científica.

Ao lado da IFSE, atuaram em cooperação mútua o Centro Latino-Americano e do Caribe de Informação em Ciências da Saúde - centro da Organização Pan-Americana da saúde.(OPAS), entidade da Organização Mundial da Saúde (OMS) para as Américas, responsável pela cooperação Técnica na área de informação em ciências da saúde para a região (BIREME), Associação Brasileira de Editores Científicos (ABEC), que atua para aumentar e aperfeiçoar a publicação de revistas científicas brasileiras, assim como para contribuir para o avanço da comunicação científica no País, e a Academia Brasileira de Ciências $(A B C)$, que, tem por princípio promover o progresso e a qualidade da ciência no Brasil.

Tanto a $10^{\mathrm{a}}$ Conferência da IFSE como outros eventos do gênero, realizados em diversas regiões do Brasil, finalizam apontando para os já conhecidos pontos críticos da editoração científica em nosso País.

Continuamos carentes de uma maior valorização das revistas nacionais pelos órgãos de fomento a pesquisa.

Muitas instituições de ensino se aventuram em iniciar uma publicação de cunho científico sem o devido planejamento quanto à sua periodicidade, dimensionamento dos custos, meios de difusão, corpo editorial, equipe de revişores, indexação em bases de dados, prevalecendo, freqüentemente, a vaidade institucional:

Os pesquisadores empenhados em sua nobre missão produzem um número razoável de trabalhos e não encontram periódicos disponíveis que possam publicar os trabalhos em um curto espaço de tempo. Na grande maioria, a tramitação do original, desde o seu recebimento até a publicação final, ultrapassa doze meses. A periodicidade declarada nem sempre corresponde à regularidade da publicação e sua respectiva pontualidade, dificultando o planejamento dos pesquisadores, instituições e empresas.

Respeitadas as características e especificidades de cada periódico, recomenda-se que as publicações não se restrinjam a uma só língua, e se adote um idioma suplementar, sugerindo-se o inglês ou o espanhol.

É também consenso geral a necessidade de uma normatização nas publicações da área de saúde e que os editores sigam correta e constantemente, facilitando a comunicação entre as bases de dados e, consequentemente, proporcionando uma maior agilização e rapidez da informação.

A iniciativa privada ainda é discreta em suas inserções publicitárias, e não reconhece as publicações científicas como um bom veículo de mídia para a divulgação de seus produtos e serviços.

A realidade das publicações científicas no Brasil, já conhecemos bastante, e podemos identificar os diversos pontos críticos. A questão, bem mais abrangente, que um simples relatório de prioridades, passa por um maior envolvimento de toda a cadeia da pesquisa científica, desde as instituições públicas e privadas, os pesquisadores, bibliotecários, indexadores, empresas e também o público leitor.

José Reinaldo Ferreira Médico Veterinário Comissão Editorial 